\title{
Antifungal Activity of Some Local Botanicals of Assam against Pythium aphanidermatum Inciting Storage Rot of Ginger
}

\author{
Sonal Kumar ${ }^{1 *}$, Ashok Bhattacharyya ${ }^{2}$, Ajit Kumar Savani ${ }^{1}$ and Sukanya Gogoi ${ }^{1}$ \\ ${ }^{1}$ Department of Plant Pathology, Assam Agricultural University, India \\ ${ }^{2}$ Director of Research, Assam Agricultural University, Jorhat- 785013, Assam, India \\ *Corresponding author
}

\section{Keywords}

Post harvest rot, Ginger, Botanicals, Allium sativum, Inhibition

Article Info

Accepted:

07 October 2019

Available Online:

10 November 2019
Pythium aphanidermatum causes post harvest rot of ginger which resulted in huge losses in quality as well as quantity of ginger. Concern over the use of agro-chemical to manage the pathogen raising the risk of food toxicity so plant extracts might be a potential alternatives to synthetic fungicides. In the study of antifungal activity of botanicals, ten botanicals (Acorus calamus, Allamanda cathertica, Allium cepa, Allium sativum, Curcuma longa, Datura wrightii, Lasia spinosa, Laurus nobilis, Ocimum sanctum and piper betle) were evaluated against Pythium aphanidermatum by poison food technique. Aqueous extracts (20\%) of A. sativum, A. cathertica and L. nobilis significantly inhibited the growth of fungal pathogen. These three most effective botanicals were further tested at four different concentrations (5, 10, 15 and 20 per cent) and highest inhibition was exhibited by $A$. sativum $(94.44 \%)$ at 20 per cent concentration followed by A. sativum (85.78\%) at 15 per cent, A. cathertica $(83.33 \%)$ at 20 per cent and $A$. sativum (76.44\%) at 10 per cent concentration.

\section{Introduction}

Ginger is the fourth most important spice in India with a production of 1047.19 thousand tons from an area of 160.48 thousand ha with productivity of 6.52 tons/ha (Annon, 201617). Globally, ginger is used in preparation of various foods for seasoning, flavoring and imparting aroma (Shukla and Singh, 2007).
Medicinal uses of Ginger has been reported as anti-nausea, anti-clotting agent, antifungal, anti-inflammatory, antiseptic, antibacterial antiviral, antitussive, analgesic, circulatory stimulant, blood flow increasing agent and so on (Gunathilake and Rupasinghe, 2015). Assam produces 156.66 thousand tons of ginger with an average productivity of 8.88 t/ha (Annon, 2016-17). After harvesting, 
ginger rhizomes are stored for seed and commercial purpose in different types of storage structures at least for a period of $6-7$ months (From Jan-Feb to Aug-Sep) for day to day fresh consumption under Assam condition. Ginger has been affected by many diseases in pre-harvest as well as post-harvest deterioration is the most important cause of loss of ginger during storage due to rotting, resulting into considerable loss to farmers. Fusarium oxysporum f. sp. zingiberi, Pythium aphanidermatum and Pseudomonas solanacearum have been reported as the major culprits for the storage rot of ginger in India (Dake and Edison, 1989; Dohroo, 1989; Sharma et al., 2017). Association of Pythium pleroticum, $P$. aphanidarmatum, $P$. equiseti and Fusarium solani with ginger rot have also been reported (Rajan and Agnihotri, 1989). For effective management of storage rot of ginger, Carbendazim, Ridomil, Topsin M etc. are generally used (Grech and Swart, 1990; Sharma and Dohroo, 1991). The side-effects of synthetic fungicides and demand of fresh products without agrochemical treatment, particularly without post-harvest agrochemical treatment forcing us to find out alternative strategies for reducing losses due to post harvest decay that are perceived as safe by the public and pose negligible risk to human health as well as environment (Wisniewski and Wilson, 1994). So there is a need for alternative(s) of chemicals for management of plant diseases.

Eco-friendly plant extracts have shown to be great potential as an alternative to synthetic fungicides (Janisiewiez and Korsten, 2002; Zhang and Zheng, 2005). As alternative of chemicals, several works have been done on management of post harvest disease that include microbial antagonists and plant extracts as potential alternatives to synthetic fungicides (Chauhan and Joshi, 1990; Sarvamangla, 1993; Chaudhary, 2003; Bhardwaj et al., 2010). They are also best suited for use in organic food production in industrialized countries but can play a much greater role in developing countries as a new class of eco-friendly organic products for controlling diseases (Isman, 2006). Ram and Thakore (2009) evaluated efficacy of 19 plant extracts against Fusarium solani and Pythium aphanidermatum and they found that A. sativum and Lantana camera were most effective in vitro. In vitro test revealed that the extract of onion, garlic and agave were highly efficacious in limiting the mycelial growth of Pythium aphanidermatum (Dohroo et al., 2012).

\section{Materials and Methods}

For evaluation of botanicals, different plant parts like i.e. fresh leaves of Acorus calamus, Allamanda cathertica, Datura wrightii, Lasia spinosa, Laurus nobilis, Ocimum sanctum and piper betle, bulbs of Allium cepa and Allium sativum, rhizome of Curcuma longa were collected from various localities of Assam for the preparation of aqueous plant extracts. The method reported by Shekhawat and Prasad (1971) was followed for botanical extracts preparation with certain modifications. Collected botanicals were washed thoroughly in sterile distilled water and crushed in grinder by adding equal amount $(100 \mathrm{ml})$ of sterilized distilled water $(1: 1 \mathrm{~W} / \mathrm{V})$. After grinding, the extract was filtered through muslin cloth and finally the extracts were centrifuged at $10,000 \mathrm{rpm}$ for 20 minutes in centrifuge (Remi C 24) at room temperature. The supernatant was taken as standard plant extract solution (100\%). The selected botanicals were first screened for their antifungal activity against Pythium aphanidermatum at 20 per cent concentration by 'poisoned food technique' (Nene and Thapliyal, 2000). For this, PDA medium was prepared in $250 \mathrm{ml}$ Erlenmeyer flasks and sterilized. Twenty (20) $\mathrm{ml}$ of 100 per cent aqueous plant extracts of each botanicals were 
aseptically added to $80 \mathrm{ml}$ molten PDA (Potato Dextrose Agar) in flasks respectively so as to get the final concentration of $20 \%$ of the extracts in the medium. PDA without any extract served as control. The media was poured in $9 \mathrm{~cm}$ Petri plates at the rate of $20 \mathrm{ml}$ per plate. The fungal culture disc using a cork borer $(5 \mathrm{~mm}$ diameter) from the tip, obtained from a 7 days old culture were taken and inoculated in the centre of Petri plates aseptically after solidification of the medium and incubated at $28 \pm 1^{\circ} \mathrm{C}$. Three most promising botanicals were further tested against Pythium aphanidermatum, in four different concentrations viz., 5, 10, 15 and 20 per cent, respectively.

The diameter of the colony is measured when the mycelium fully covered the Petri plates of control plate and the percent inhibition of the mycelial growth was calculated by the formula of Vincent (1927).

$\mathrm{I}=\frac{(\mathrm{C}-\mathrm{T})}{\mathrm{C}} \times 100$

Where, I = Inhibition of mycelial growth (\%)

$\mathrm{C}=$ Growth in control $(\mathrm{mm})$

$\mathrm{T}=$ Growth in treatment $(\mathrm{mm})$

Five replications were maintained for each concentration of the treatments in a completely randomized design. The observed data was analyzed by OPSTAT package of programs (Sheoran, 2006) after angular transformation.

\section{Results and Discussion}

The results (Table 1) indicated that some botanicals significantly reduced the mycelial growth of the pathogen while other showed less inhibition over control $(90 \mathrm{~mm})$. Among the all ten botanicals tested $A$. sativum recorded highest inhibition (94.44\%) followed by $A$. cathertica (83.33\%), L. nobilis (68.66\%) and A. calamus (57.55\%). Per cent mycelial growth inhibition recorded in $C$. longa $(54.22 \%)$ followed by L. spinosa $(35.55 \%)$ and D. wrightii $(35.11 \%)$. The per cent inhibition in A. cepa, $O$. sanctum and $P$. betle were recorded as $(28.44 \%),(19.77 \%)$ and $(12.66 \%)$ respectively.

Perusal of the data (Table 2 and Fig. 1) revealed that irrespective of different concentrations, all the botanicals showed significantly higher inhibitory effect on the mycelial growth of $P$. aphanidermatum as compared to control and highest inhibition was recorded in A. sativum followed by $A$. cathertica and L. nobilis respectively. Among the three botanicals tested at four different concentrations $(5 \%, 10 \%, 15 \%$, and $20 \%)$, the maximum mycelial inhibition was recorded in A. sativum $(94.44 \%)$ at 20 per cent concentration which was found to be significantly superior over rest of treatments. This was followed by A. sativum (85.78\%) at 15 per cent, $A$. cathertica $(83.33 \%)$ at 20 per cent and $A$. sativum (76.44\%) at 10 per cent. The effect of $A$. cathertica $(67.56 \%)$ at 10 per cent was statistically at par with $L$. nobilis (68.67\%) at 20 per cent, similarly the effect of A. sativum (68.67\%) was at par with L. nobilis $(68.67 \%)$ at 20 per cent. The least inhibition of mycelial growth of $P$. aphanidermatum was observed in L. nibilis (46.67\%) at 5 per cent. Irrespective of concentrations of plant extracts, A. sativum recorded maximum mean growth mycelial inhibition $(81.33 \%)$ followed by $A$. cathertica $(71.72 \%)$ and minimum mean mycelial growth inhibition was recorded in $L$. nobilis $(58.72 \%)$.

Amongst the tested botanicals, bulb extracts of A. sativum recorded highest inhibition on mycelial growth of the pathogens followed by $A$. cathertica and L. nobilis respectively. The results of the present study are in agreement 
with those reported by several workers (Vijaya et al., 2007; Ram and Thakore, 2009; Jadhav et al., 2013; Chaudhary et al., 2017) who reported A. sativum highly effective against many fungal pathogens.

Table.1 Efficacy of different botanicals (20\%) on mycelial growth of Pythium aphanidermatum

\begin{tabular}{|c|c|c|}
\hline Treatments & $\begin{array}{c}\text { Mycelial growth* } \\
(\mathbf{m m})\end{array}$ & $\begin{array}{c}\text { Mycelial growth inhibition } \\
\text { over control }(\%)\end{array}$ \\
\hline T1: Acorus calamus & 38.20 & $57.55(49.32)^{* *}$ \\
\hline T2: Allamanda cathertica & 15.00 & $83.33(65.88)$ \\
\hline T3: Allium cepa & 64.40 & $28.44(32.21)$ \\
\hline T4: Allium sativum & 5.00 & $94.44(76.33)$ \\
\hline T5: Curcuma longa & 41.20 & $54.22(47.40)$ \\
\hline T6: Datura wrightii & 58.40 & $35.11(36.31)$ \\
\hline T7: Lasia spinosa & 58.00 & $35.55(36.58)$ \\
\hline T8: Laurus nobilis & 28.20 & $68.66(55.94)$ \\
\hline T9: Ocimum sanctum & 72.20 & $19.77(26.38)$ \\
\hline T10: Piper betel & 78.60 & $12.66(20.82)$ \\
\hline T11: CoC $(\mathbf{0 . 3 \%})$ & 0.00 & $100.00(89.55)$ \\
\hline T12: Control & 90.00 & $00.00(3.69)$ \\
\hline SEd $(\mathbf{(})$ & & 0.60 \\
\hline CD $(\mathbf{p}=\mathbf{0 . 0 5})$ & & 1.22 \\
\hline
\end{tabular}

*Mean of five replication

** Data in parentheses represents angular transformation

Table.2 Efficacy of botanicals (5, 10,15 and 20\%) on mycelial growth of Pythium aphanidermatum

\begin{tabular}{|c|c|c|c|c|c|c|}
\hline \multirow[t]{2}{*}{ SI. No. } & \multirow[t]{2}{*}{ Treatments } & \multicolumn{4}{|c|}{$\begin{array}{c}\text { Mycelial growth inhibition over control } \\
(\%)\end{array}$} & \multirow[t]{2}{*}{$\begin{array}{l}\text { Mean } \\
(\mathbf{m m})\end{array}$} \\
\hline & & 5 & 10 & 15 & 20 & \\
\hline 1 & Allamanda cathertica & $\begin{array}{c}61.33 \\
(51.55)^{*}\end{array}$ & $\begin{array}{c}67.56 \\
(55.28)\end{array}$ & $\begin{array}{c}74.67 \\
(59.78)\end{array}$ & $\begin{array}{c}83.33 \\
(65.90)\end{array}$ & $\begin{array}{c}71.72 \\
(58.13)\end{array}$ \\
\hline 2 & Allium sativum & $\begin{array}{c}68.67 \\
(55.96)\end{array}$ & $\begin{array}{c}76.44 \\
(60.98)\end{array}$ & $\begin{array}{c}85.78 \\
(67.85)\end{array}$ & $\begin{array}{c}94.44 \\
(76.36)\end{array}$ & $\begin{array}{c}81.33 \\
(65.29)\end{array}$ \\
\hline 3 & Laurus nobilis & $\begin{array}{c}46.67 \\
(42.96)\end{array}$ & $\begin{array}{c}56.44 \\
(48.70)\end{array}$ & $\begin{array}{c}63.33 \\
(52.73)\end{array}$ & $\begin{array}{c}68.67 \\
(55.94)\end{array}$ & $\begin{array}{c}58.72 \\
(50.08)\end{array}$ \\
\hline & $\mathrm{CoC}(0.3 \%)$ & 100.00 & 100.00 & 100.00 & 100.00 & \\
\hline & Control & -- & -- & -- & -- & \\
\hline & & \multicolumn{2}{|c|}{ Botanicals (B) } & \multicolumn{2}{|c|}{ Concentrations (C) } & $\begin{array}{c}\text { Interaction } \\
(\mathrm{B} X \mathrm{C})\end{array}$ \\
\hline & SEd $( \pm)$ & \multicolumn{2}{|c|}{0.23} & \multicolumn{2}{|c|}{0.26} & 0.46 \\
\hline & $\mathrm{CD}(\mathrm{p}=0.05)$ & \multirow{2}{*}{\multicolumn{2}{|c|}{0.46}} & \multirow{2}{*}{\multicolumn{2}{|c|}{0.53}} & 1.24 \\
\hline & CV (\%) & & & & & 1.26 \\
\hline
\end{tabular}

* Data in parentheses represents angular transformation 
Fig.1 Efficacy of botanicals (5, 10, 15 and 20\%) on mycelial growth of $P$. aphanidermatum (after 8 days of inoculation)

Allamanda cathertica

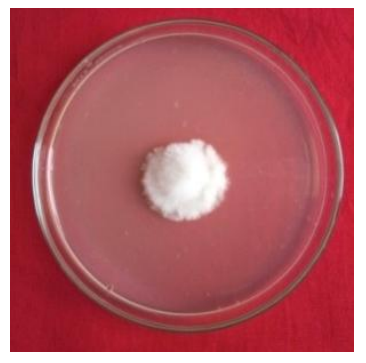

$5 \%$

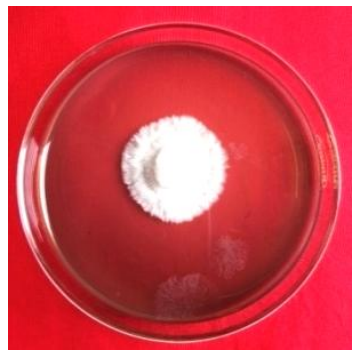

$5 \%$

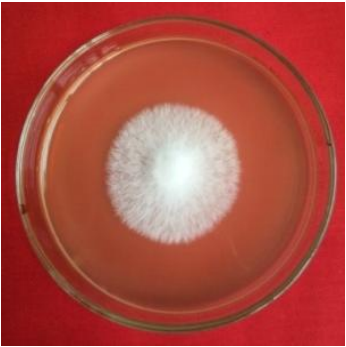

$5 \%$

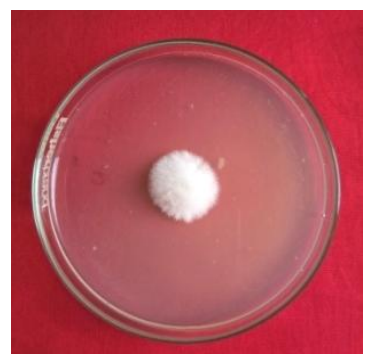

$10 \%$

Allium sativum

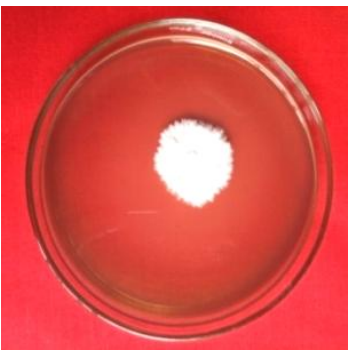

$10 \%$

\section{Laurus nobilis}

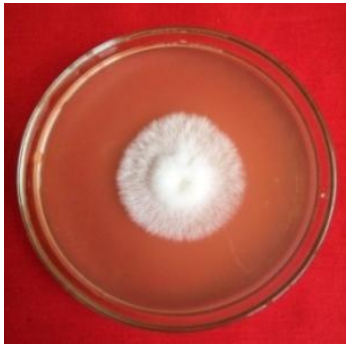

$10 \%$

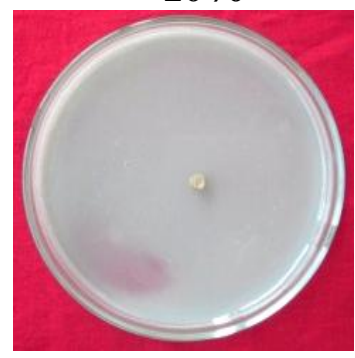

$\operatorname{CoC}(0.3 \%)$

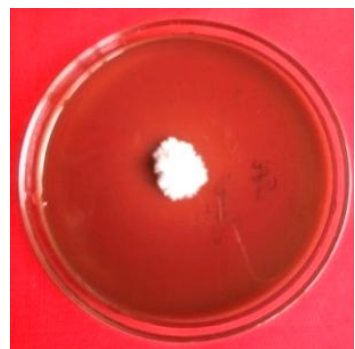

$15 \%$

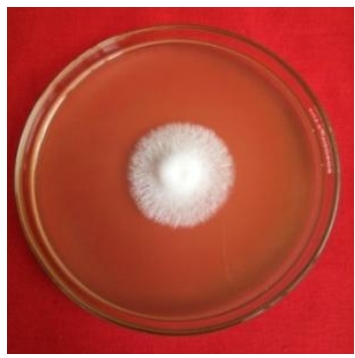

$15 \%$

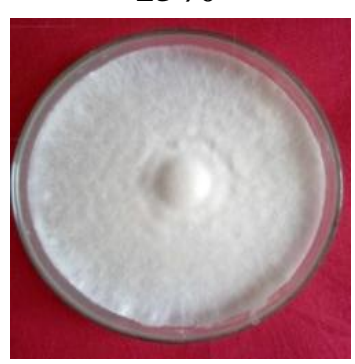

Control

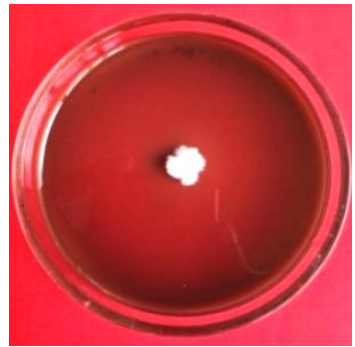

$20 \%$

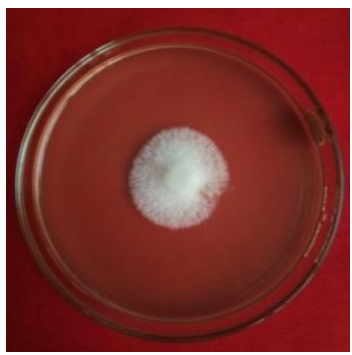

$20 \%$ 
Plant based pesticides i.e. botanicals being relatively economical, safe and nonhazardous show antifungal activity against many fungal pathogens (Vijaya et al., 2007; Ram and Thakore, 2009; Jadhav et al., 2013; Chaudhary et al., 2017). On the other hand, Assam as well as other North East states of India is well known for the rich biodiversity.

Hence, use of rich potential of the botanicals available in the state may be a comparative advantage and an alternative for the management of plant disease diseases. Ecofriendly management approach like use of botanicals more particularly $A$. sativum, $A$. cathertica and $L$. nobilis may be used as an integral part of integrated disease management and it also has prospect as an alternative to reliance only on fungicide.

\section{Acknowledgement}

Author thanks the major advisor Dr. Ashok Bhattacharyya for consistent guidance during whole research work and also thank the Head of the Department of Plant Pathology for providing all necessary laboratory facilities.

\section{References}

Anonymous.

(2016-17). http://indianspices.com

Aqili-khorasani, M.S. (1992). Collection of drugs (material medica). Enghelab-eEslami Publishing and Educational Organization, Tehran, pp. 624-630.

Bhardwaj, A., Vinothkumar, K. and Rajpara, N. (2013). Bacterial quorum sensing inhibitors: attractive alternatives for control of infectious pathogens showing multiple drug resistance. Recent Pat. Antiinfect. Drug. 8: 68-83.

Chauhan, H. L. and Joshi, H. U. (1990). Evaluation of phyto-extracts for control of mango fruit anthracnose In: Botanical pesticides in integrated pest management: Proceedings of National Symposium held on January 21-22, 1990 at Central Tobacco Research Institute, Rajahmundry 533 105, India. Ind. Society of Tobacco Sci. pp. 455459.

Choudhary, R. F., Patel, R. L., Chaudhari, S. M., Pandey, S. K. and Singh, B. (2003). In vitro evaluation of different plant extracts against Alternaria alternata causing early blight of potato. J. Indian Potato Assoc. 30: 141-142.

Choudhary, R., Kakraliya, S. S., Sheshma, M. K. and Bajiya, M. R. (2017). Bioefficacy of few plant extracts/botanicals against damping off of brinjal (Pythium ultimum). Int. J. Chem. Sci. 1: 1-3.

Dake G. N. and Edison, S. (1989). Associtaion of pathogens with rhizome rot of ginger in Kerala. Indian Phytopathol. 42: $116-119$

Dohroo, N. P. (1989). Seed transmission of pre-emergence rot andyellows in ginger. Pl. Dis. Res. 4: 73-74

Dohroo, N. P., Kansal, S., Mehta, P. and Ahluwalia, N. (2012). Evaluation of eco-friendly disease management practices against soft rot of ginger caused by Pythium aphanidermatum. Pl. Dis. Res. 27: 1-5.

Grech, N. M. and swarts, D. H. (1990). Postharvest application of fungicides for control of fungal decay of ginger rhizomes stored under simulated low temperature shipping conditions. Phytophylactica. 22: 457-458.

Gunathilake, K. and Rupasinghe, H. (2015). Recent perspectives on the medicinal potential of ginger. Botanics. 5: 55-63.

Isman, M. B. (2006). Botanical insecticides, deterrents, and repellents in modern agriculture and an increasingly regulated world. Annu. Rev. Entomol. 51: 45-66. 
Jadhav, S. N., Aparadh, V. T. and Bhoite, A. S. (2013). Plant extract using for management of storage rot of ginger in Satara Tehsil (M.S.). Internat. J. Phytopharm. Res. 4: 1-2.

Janisiewiez, W. J. and Korsten, L. (2002). Biocontrol of post harvest disease of fruits. Annu. Rev. Phytopathology. 40: 411-441

Mone, M., Saieed, M. A. U., Dastogeer, K. M. G., Ali, M. A. and Meah, M. B. (2014). Plumieride from Allamanda cathartica as an inhibitory compound to plant pathogenic fungi. Arch Phytopathology Plant Protect. 47: 1311-1326.

Nayak, S., Nalabothu, P., Sandiford, S., Bhogadi, V. and Adogwa, A. (2006). Evaluation of wound healing activity of Allamanda cathartica L. and Laurus nobilis L. extracts on rats. BCM Compl.Altern. Med. 6: 12.

Nene, Y. L. and Thapliyal, P. N. (2000). Fungicides in Plant Disease Control. (5th ed.) Oxford and IBH publishing Co. Pvt. Ltd., New Delhi. p. 325

Rajan, K. M. and Agrihotri, V. P. (1989). Pythium induced rhizome rot of ginger: Problem and Progress In: Prospectives in Phytopathology. New Delhi, India. Todays and Tomorrows Printers and publishers: 189-198 (ISBN 817019-3346)

Ram, J. and Thakore B. B. L. (2009). Management of storage rot of ginger by using plant extracts and biocontrol agents. J. Myco. Pl. Patho. 39: 475479

Sarvamangla, H. S. (1993). Evaluation of plant extract for the control of fungal disease of blackberry. Indian Phytopathol. 46: 398-401

Seyed, M., Riaz, M. and Chaudhary, F. M. (1991). The antibacterial activity of the essential oil of the Pakistani Acotus calmus, Callistemon lanceolatus and
Laurus nobilis. Pak. J. Sci. Ind. Res. 34: 456-458.

Sharma, S. K. and Dohroo, N. P. (1991). Post harvest management of Rhizome rot (Fusaruim oxysporum f. sp. zingiberi Trujillo) of ginger through chemical and antagonist. Indian Cocoa Arecanut Spices J., 14:150-152.

Sharma, S., Dohroo, N. P., Veerubommu, S., Phurailatpam, S., Thakur, N. and Yadav, A. N. (2017). Integrated Disease Management of Storage Rot of Ginger (Zingiber officinale) caused by Fusarium sp. in Himachal Pradesh, India. Int. J. Curr. Microbiol. App. Sci. 6: 3580-3592.

Shekhawat, P. S. and Prasad, R. (1971). Antifungal properties of some plant extracts and their inhibition of spore germination. Indian Phytopathol. 24: 800-802.

Sheoran, O. P. (2006). Online statistical analysis tool (OPSTAT). www.hau.emet.in/about/opstat.php. CCS HAU, Hissar

Shukla and Singh (2007). Cancer preventive properties of ginger: a brief review. Food Chem. Toxicol, 45: 683-690.

Singh, U. P., Prithiviraj, B., Wagner, K. G. and Schumacher, K. P. (1995). Effect of ajoene, a constituent of garlic (Allium sativum) on powdery mildew (Erysiphe pisi) of pea (Pisum sativum). J. Plant Dis. Prot. 102: 399-406.

Vijaya, H. K., Srikant, K. and Hegde, Y. R. (2007). Evaluation of plant extracts against Ceratocystis paradoxa causing sett rot of sugarcane. Karnataka J. Agril. Sci. 20: 168-169.

Vincent, J. M. (1927). Distortation of fungal hyphae in presence of certain inhibitors. Nature. 159: 850

Wisniewski, M. E. and Wilson, C. L. (Eds.). (1994). Biological control of postharvest diseases: theory and practice. CRC press, Kearneysville, 
USA

325-328.

Yoshida, S., Kasuga, S., Hayashi, N., Zhang, H. and Zheng, X. (2005). Biological Ushiroguchi, T., Matsuura, H. and control of postharvest blue mold of Nakagawa, S. (1987). Antifungal oranges by Cryptococcus laurentii activity of ajoene derived from garlic. Appl. Environ. Microbiol. 53: 615-617. (Kufferath) Skinner. Biocontrol, 50: 331-342

Zargari, A. (1990). Medicinal Plants, Vol. IV.

Tehran University Press, Tehran, pp.

\section{How to cite this article:}

Sonal kumar, Ashok Bhattacharyya, Ajit Kumar Savani and Sukanya Gogoi. 2019. Antifungal Activity of Some Local Botanicals of Assam against Pythium aphanidermatum Inciting Storage Rot of Ginger. Int.J.Curr.Microbiol.App.Sci. 8(11): 528-535.

doi: https://doi.org/10.20546/ijcmas.2019.811.065 